\title{
Changes in Celestial Journey Literature: 1400-1650
}

\author{
Alan S.Weber*

\section{Introduction}

This study investigates an important historical phase in the curiously hybrid genre of the celestial journey narrative which has produced not only important scientific texts, such as Macrobius's Somnium Scipionis, but also some of Western Europe's finest poems, including Dante's Divine Comedy. I would like to compare Christine de Pizan's Chemin de Long Estude of 1403, which describes the author's celestial journey through the heavenly spheres, to another milestone in celestial voyage literature, Francis Godwin's English work The Man in the Moone of 1638. These two literary and historical endpoints illustrate the changes in European technical astronomy which occurred between 1400 and 1650, and also reveal the shift which occurred in the very nature of the celestial voyage genre. I will also briefly review other closely related early modern celestial voyage narratives written by Johannes Kepler and Bishop John Wilkins.

The True History of Lucian of Samosata (born circa 117 C.E.), the satirical story of the author's trip to the moon, is often cited as a seminal text in the tradition of celestial journey literature because it contains one central element common to all narratives of this type: expansiveness. I mean here expansiveness in all its senses; Lucian undertakes the ultimate journey, past the pillars of Heracles, the limit of the known classical world, and this breaking of boundaries allows him to overstep other restrictions on etiquette, mores, and good taste. This expansiveness also allows him to satirize Homer, Socrates, Heracles, Aristophanes, and Dionysus with impunity.

Similarly, the breadth of the genre allowed an early medieval textbook writer, Macrobius (circa late fourth century C.E.) to use his celestial wanderings through the planetary spheres as the pretext for a journey into the secrets of Pythagorean number symbolism and the cosmology of Plato's Timaeus. One of the great poems of celestial journeying, Dante's Divine Comedy, closely resembles both Lucian and Macrobius in its use of the movement metaphor to explore, magnify, and expatiate upon unknown physical and epistemological territory. As he physically 
encompassed vast spaces, Dante also explored great ethical, spiritual, scientific, and theological truths, presenting his poem as an encyclopedia of both theology and cosmology. Dante was the direct inspiration for Christine de Pizan's celestial voyage in the Chemin de Long Estude; she certainly drew her encyclopedic purpose from him. Her poem therefore represents an excellent mirror of the cosmological thought of her day as she interpreted it within a tradition well known to her.

\section{Christine de Pizan's Cosmology}

The life and works of Christine de Pizan (1364-c.1430) have recently received renewed attention as evidenced by the numerous translations and critical studies of her works as well as the international conferences held in her honor during the last ten years. Christine was born in Venice in 1364, the daughter of Thomas of Pizan, who later became court astrologer to Charles V of France. Thomas of Pizan [or Bologna] taught astrology at Bologna from 1345 to 1356 . He is well known for the magical charm he used to expel the invading English armies from French soil by burying wax images of the English commanders at various locations throughout the French kingdom.

Christine grew up in the learned atmosphere of the court of the French King Charles V. She began to write extensively in the 1390s after the death of her husband Etienne de Castel. Along with a biography of King Charles V, she produced a large corpus of short lyrics, longer narrative poems, and a series of didactic works on the position of women in 14th Century society. She became well known to her contemporaries through her debate with Jean de Montreuil, Gonthier Col, and Jean Gerson over the alleged obscenity and misogyny of Jean de Meun's popular poem Le Roman de la Rose.

The recent recovery of one of Christine de Pizan's neglected works, Le Livre du Chemin de Long Estude (1403), has involved the steady critical appreciation of a dream vision dismissed in the last century by Gaston Paris as a mediocre text, with some potential value, however, for the history of ideas. ${ }^{1}$ The poem opens with Christine's ruminations on her recently deceased husband and the vicissitudes of Fortuna. She then ponders the sources of evil and change in the world, attributing mutation to the battle of the elements: 'fire and water hate each other/ And one desires to destroy the other'. ${ }^{2}$ This is probably an example of the type of passage which Gaston Paris believed important for the history of ideas. From her descriptions of the heavens in the opening sections of the poem, it is abundantly clear that Christine endorses the standard Aristotelian- 
Ptolemaic model of the universe, so called because of its fusion of the fundamental principles of Aristotelian physics with Ptolemy's system of epicycles and geometrical determination of planetary orbits. Although the Aristotelian-Ptolemaic model remained the standard orthodoxy in western European universities during Christine's day, there were serious challenges to it throughout the Middle Ages, including such works as Bernardus de Silvestris's Cosmographia, which drew on Stoic, Hermetic, and Platonic thought. ${ }^{3}$ It would be too simplistic, however, to divide medieval cosmology into Aristotelian and non-Aristotelian camps. Even astrology, which has often been portrayed in modern historiography as the antithesis of both Aristotelian cosmology and modern mathematical astronomy, was firmly rooted in the physical principles expounded in Aristotle's De Caelo, De Generatione et Corruptione, and the Meteorologica. As Richard Lemay observes, 'there can be little doubt that [Aristotle's works] supplied the scientific background of astrology during 2000 years after him'. As we shall soon see, the European cosmology of Christine's age also eclectically adopted Stoic and Platonic ideas enriched by Arabic interpretations of Greek astronomy. Thus, European cosmology of the early modern period should not be characterized as slavish scholastic repetition of Aristotelian science, but by a richness of perspective, and Christine's interpretation of celestial science, which defines astronomy as a medium or bridge between divine and human knowledge, should not be lightly dismissed.

The greatest challenge to Aristotle's cosmological system ironically came from scholastic Christian theology itself, as evidenced by Bishop Etienne Tempier's condemnation in 1277 of 219 scholastic theses about the universe. Christine, however, does not mention any of the serious cosmological incompatibilities and tensions between Christianity and Aristotle, such as the question of the eternity of the world or the debate over the plurality of worlds. ${ }^{5}$ Christine 'never ceases to consider Aristotle as the prince of philosophers' and liberally quotes extracts from Thomas Aquinas's commentary on Aristotle's Metaphysics in Le Livre des Fais et Bonnes Meurs du Sage Roy Charles $V .{ }^{6}$ The Metaphysics also informs a large part of book two of L'Avision Christine, which may represent, as Glenda McLeod suggests, the first known vernacular commentary on Aristotle's Metaphysics. ${ }^{7}$

To return to Christine's narrative, she falls asleep during her reading and is visited by Sebille (Sybil) who announces that she will tell Christine the secrets of the universe because Christine is ready to conceive great knowledge ('apprestee a concevoir'). ${ }^{8}$ The double-entendre implicit in 
conceiving knowledge points to an important aspect of Christine's conception of science: she conceives of knowledge not as a body of facts brought from the outside world into the mind, but as an internal process of spiritualization, a birth of inward light.

Sebille next leads Christine to the fountain of Sapience, where all the great philosophers have drunk, including Socrates, the Cynics, Plato, Hermes, Seneca and her father Thomas of Pizan. From the fountain they proceed to the road of long study, a path well known to Christine. After whisking Christine around the various kingdoms of the world, Sebille leads her upwards to a high mountain, where she hears a clamour of Greek voices, no doubt the arguments of Stoics, Epicureans, Platonists, Skeptics, and Peripatetic philosophers all advancing their specific world views. Sebille next invites Christine to mount a subtle ladder extending from the heavens:

Light it was and portable

As if one could twist it around

And carry it without labour

Everywhere, if you wanted.

You would never be hindered or bothered by it.

It was not made of rope

Nor any kind of cord or wood.

I could not determine the material

But it was long, strong, and light. ${ }^{9}$

Sebille calls the curious and resplendent device 'l'eschiele de Speculacion' - the ladder of speculation - a shining entranceway into the heavens ordained for those, who like Christine, love subtlety and learning. Now begins her ascent into the celestial spheres offering her the occasion to detail the structure of the heavens for the reader.

Christine and Sebille first pass through the first heaven ('premier ciel'), which is made out of air. From there, they pass into the second heaven, the 'ether', characterized by its shining brilliance and clarity. Instead of the common Aristotelian definition of the ether as the fifth element (quinta essentia) comprising the stars and existing only beyond the sphere of the moon, Christine accepts the Stoic conception of the ether as the purer part of the upper air. They next continue on into the third heaven or the sphere of fire, traditionally located under the sphere of the moon in Aristotelian cosmology. They continue on into the fourth heaven, called 'Olimpe', meant to recall Mount Olympus, the seat of the 
pagan gods and a general epithet in Old French for sky or heaven. Christine's ladder finally ends within the fifth heaven, 'le firmament', a place of pervasive and blinding light.

It is here, in the fifth heaven, that Christine receives a lesson in both astronomy, the science of the movements of the fixed and wandering stars (planets), and in astrology, the knowledge of the powers and influences exerted by those celestial bodies: ${ }^{10}$

[Sebille] showed me everything, and told me the names and powers of the planets, and she made every effort to teach me the courses of the moving stars, both the fixed and the wandering. And she told me the properties, the effects, the contraries, the powers and the influences, and their various arrangements. ${ }^{11}$

After her description of the physical structure of the heavens, Christine curiously admits her inability to provide the reader with any further details, because she had not learned astrology at school. ${ }^{12}$ Undoubtedly she knew of the technical treatises in the library of her astrologer father Thomas of Pizan, who must have possessed a collection of astrological texts as well as instruments, but how far she proceeded in her studies cannot be determined with any accuracy.

Both Edgar Laird and Charity Cannon Willard have demonstrated how astrology formed one of the central concerns of the learned court, which included Thomas, assembled by le Sage Roy Charles V. ${ }^{13}$ The court of Charles V was very much a centre of scientific learning, especially of Aristotelianism. Charles had commissioned Nicole Oresme to translate the works of Aristotle into the vernacular. Oresme (c.1320 - 1382) was a Professor of Theology at the College of Navarre in Paris. He made great contributions to mathematics and physical science, and wrote several cosmological works on astronomy (De l'Espere), divination (Livre de Divinacions), and astrology (Tractatus Contra Judicarios Astronomos). The King was also a great patron of astrologers and founded the 'Collège de Maitre Gervais' at the University of Paris for the study of astrology. Lynn Thorndike remarks about the court of Charles V: 'at this period wisdom and astrology were considered almost synonymous', ${ }^{14}$ a viewpoint that constantly surfaces in Christine's works.

One source of Christine's astrological learning may have been one of the texts which went by the name of On the Sphere, such as Nicole Oresme's De l'Espere (late 14th Century). ${ }^{15}$ Christine's description of the heavens echoes De l'Espere in several respects: both authors characterize 
the earth as a round ball as viewed from the moon. Both Christine and Oresme divide the heavens into five regions (in Oresme, three regions of the air, the sphere of fire, and the heavens). Oresme also mentions that Mount Olympus reaches into the upper air and Christine names one of her heavens 'Olimpe' in the Chemin de Long Estude.

Christine also makes reference in her poem to a wide variety of eclectic cosmological doctrines such as the planetary houses, the music of the spheres, and cosmic plenitude. She observes on her journey the houses of the planets ('les maisions que planetes ont'), and in which houses they are exalted ('quelles ont exaltacion'). ${ }^{16}$ She also describes the music of the spheres, the ordered movements of the heavens comprising 'l'armonie et belle chancon', a Platonic and Pythagorean idea widely disseminated in medieval literature despite Aristotle's skeptical rejection of the doctrine. ${ }^{17}$ Her descriptions of the great number of heavenly bodies - 'la grant quantité pleniere/ Qui y est' ${ }^{18}$ - reinforces the Aristotelian, Stoic, and later Christian idea of the plenitude of the cosmos. Scholastic Christian theology generally endorsed the idea of the Aristotelian and Stoic plenum, the absence of any empty space in the universe, in response to the inane or kenon (void space) of Epicurean physics which had denied divine providence and ordered causality. Void space implied a location where God was not, an affront to the creator's omnipresence. It is Christine's wonder at the plenitude of created nature which invites her to make her explorations through the celestial spheres.

Christine, however, finds that she cannot enter the Crystalline Heavens to see the nine orders of angels because of the present state of her corporeal body. ${ }^{19}$ Sebille and Christine therefore descend to the sphere of the air, near the ethereal layer. There she meets the servants ('maigniee') of the 'intelligences haultaines,' the followers of the planets, sun, moon and other intelligences who are called Influences and Destinies. These Influences and Destinies are beings attached to every planet, intelligence, star, and heaven who serve them like household retainers. ${ }^{20}$ Although she does not describe these beings at any length, they obviously act as mediums, messengers, and conduits between the divine powers of the heavenly bodies and material bodies on earth. In this section Christine seems to argue for complete astrological determinism, that our fates have been predestined by heavenly confluence. Yet she does remind her readers that God still rules the destinies from above:

...as soon as a man or a woman is born, however great, the destinies control their lives and assign them their proper end, good or evil, 
according to the domain of the course of the planets at the hour when the infant is born. But nevertheless God, who has given them this power, reigns above and takes care of what pleases Him. ${ }^{21}$

Among the Destinies, Christine sees the rebellions, treasons, destroyed towns, and tempests of the evil fortunes about to be rained down on earth by the Influences. She even boasts of some prophetic knowledge: she says she now knows what the effects of the 1401 comet will be; but these effects, which she refuses to reveal to the reader, will not unfold for another 20 years. ${ }^{22}$ The latter part of the Chemin de Long Estude consists of a court held by Queen Reason in which the four estates (Sagesse, Richesse, Chivalrie, and Noblesse) debate the proper virtues pertaining to the prince. Although to modern readers the second part of the poem may seem like a mirror for magistrates, or a conduct book such as Christine's Treasure of the City of Ladies, tacked on to an exposition of natural philosophy, I will argue later, after a description of Francis Godwin's work, for the essential unity of the poem. The jugement genre, highly developed by Machaut, ${ }^{23}$ in which a central question is debated in a real or mock court by learned advocates, dovetails perfectly with Christine's encyclopedic introductory section of the Chemin de Long Estude since the jugement allows for the airing of diverse opinions, just as the tradition of commentary on Aristotle weighed and synthesized conflicting propositions on the nature of the cosmos. As Barbara K. Altmann aptly puts it: 'what more suitable forum for intricate argument than a courtroom scene, where a minimum of plot could supply a certain amount of tension as to outcome and where characters of allegorical or human nature could quite justifiably defend conflicting opinions at length? ${ }^{24}$

\section{Godwin, Kepler and Wilkins}

Separated in culture and time by over 200 years, Francis Godwin's Man in the Moone ${ }^{25}$ (published 1638) nevertheless stands in direct line with Christine's Chemin de Long Estude; both works form part of the larger tradition of celestial journeys established by Lucian, Macrobius, and Dante. ${ }^{26}$ Bishop Francis Godwin is best known for his Catalogue of the Bishops of England since the first planting of Christian Religion in the Island, etc., for which he was awarded the bishopric of Llandaff by Queen Elizabeth. ${ }^{27} \mathrm{He}$ was one of a growing number of English clergymen, including Bishop John Wilkins, who took a serious interest in scientific matters and who attempted to reconcile astronomical advancements with divine writ. Godwin was writing after the detailed 
observational work of Tycho Brahe, later published by Johannes Kepler, and the De Revolutionibus (1543) of Copernicus, which had proposed a heliocentric universe and rotating earth while retaining the fundamental Ptolemaic principles of circular motion and epicycles. After Tycho's parallax measurements of the 1577 comet had situated this extraordinary cosmic event well beyond the lunar sphere - in other words a decaying, changing object had appeared in Aristotle's alleged realm of perfection Aristotelian cosmology, already damaged by Copernicanism, began seriously to unravel. ${ }^{28}$ Godwin was also writing after the telescopic discoveries of Galileo reported in the Siderius Nuncius (1611).

In Godwin's work Domingo Gonsales, a Spanish Hidalgo, narrates his remarkable life story. After killing a man in a duel, Gonsales departs on a series of sea voyages which finally land him on the island of St. Helena. He discovers huge geese there - gansas - which he trains to carry heavy loads. He invents a flying machine by tying the gansas together, eventually flies off the island and is picked up by a Spanish ship. He convinces the captain to take the birds aboard, and soon after, the Spanish fleet is defeated by the English navy. Gonsales escapes with his gansas who inexplicably fly straight upwards into the atmosphere towards the moon. On his lunar voyage he encounters pleasing shapes floating in the air who bring him delicious foods. When he reaches the moon, on September 21, 1599, he finds that the food given to him by the aerial beings has turned to 'a mingle mangle of dry leaves, of Goats haire, Sheepe, or Goats-dung, Mosse, and such like trash'. ${ }^{29} \mathrm{He}$ has been deceived by wicked spirits.

As Gonsales arrives on the moon, we begin to see Godwin's somewhat transparent purpose in writing this narrative - he uses Gonsales to advance contemporary cosmological doctrines. In a similar fashion, Christine's journey had allowed her to provide an eyewitness account of the true order of the heavens. First, Gonsales refutes the existence of the 


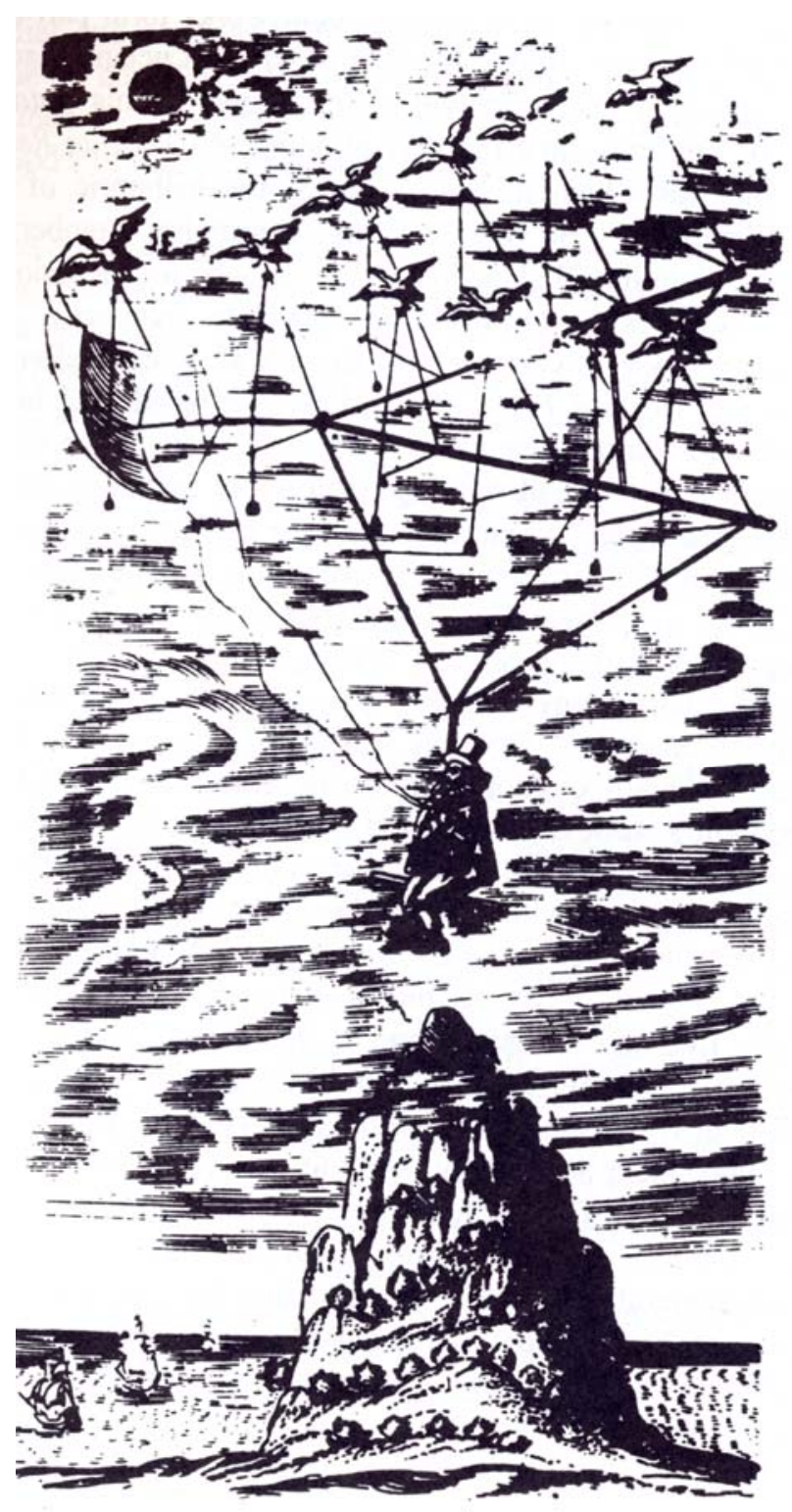

Gonsales en route to the Moon,

from Godwin's The Man in the Moone (1638) 
Aristotelian sphere of fire, a ring of elemental fire attached to the upper air. Gonsales discovers that the upper air is of the same temperature as that below: 'Who is there that hath not hitherto believed the uppermost Region of the Ayre to be extreme hot, as being next forsooth unto the naturall place of the Element of Fire. O Vanities, fansies, Dreames! ${ }^{30}$

We remember in Christine's poem how she fears the increasing heat as she mounts the ladder of speculation towards the Aristotelian sphere of fire. ${ }^{31}$ She recalls the arrogance of Icarus who flew too high and presumptuously into the fiery heavens. Godwin, on the other hand, following common practice among professional astronomers of his age, has rejected the existence of the sphere of fire. ${ }^{32}$ By the beginning of the seventeenth century, Stoic and Hermetic monism (universally operating physical law) began to supersede Platonic and Aristotelian dualism in physics (separate physical laws for heaven and earth), a development which challenged the doctrine of the elemental spheres.

Godwin also questions the Aristotelian idea of the natural place of the elements which made the centre of the earth the point towards which the heavier elements earth and water were attracted. In Godwin's cosmological system, magnetic force, an idea previously outlined in William Gilbert's widely read De Magnete (1600), replaces the natural place of the earth as a centre of attraction. This modification allows for the moon to possess a centre of attraction, ${ }^{33}$ which Gonsales discovers as he walks on the moon. The lesser magnetic force of the moon allows him to bound high into the air.

Most importantly, Gonsales watches the earth turning on its axis from his position on the moon. He must therefore conclude along with the Copernicans that the earth spins on its axis every twenty four hours from west to east. We are very far away from Christine's fixed earth which she sees from above, sitting 'like a little, round ball' ${ }^{34}$ Gonsales now realizes the blindness of the philosophers who posit two contrary motions for the heavens and the planets:

Philosophers and Mathematicians I would should now confesse the wilfulnesse of their own blindnesse. They have made the world believe hitherto, that the Earth hath no motion. And to make that good, they are fain to attribute unto all and every of the celestiall bodies two motions, quite contrary each to other; whereof one is from the East to the West, to be performed in 24 hours; (that they imagine to be forced, per raptum primi Mobilis) the other from the West to the East in severall proportions. ${ }^{35}$ 
Godwin and Gonsales, however, do not fully accept the Copernican hypothesis. Gonsales states:

I will not go so far as Copernicus, that maketh the Sunne the Center of the Earth, and unmoveable, neither will I define any thing one way or other. Only this I say, allow the Earth his motion (which these eyes of mine can testifie to be his due) and these absurdities are quite taken away, every one having his single and proper Motion onely. ${ }^{36}$

Godwin's work has many affinities with Johannes Kepler's Somnium, a work on lunar astronomy published in 1634 . With the aid of his mother, Kepler, who appears in the work as the character Duracotus, summons a demon who explains life on his home planet of Levania (the moon). Kepler uses this fiction, based on Lucian's True History, much in the same way as Godwin - to explicate lunar astronomy by shifting observational reference points from the earth to the moon. Thus, in his highly technical notes to the Somnium, Kepler explains eclipses, solstices, and lunar and terrestrial rotation as measured from the moon as a central reference point. Just as Godwin employed the fiction of the celestial journey to argue for terrestrial rotation, so Kepler states in his notes: 'here is the thesis of the whole Dream; that is, an argument in favour of the motion of the earth or rather a refutation of the argument, based on sense perception, against the motion of the earth'. ${ }^{37}$

John Wilkins' The Discovery of A World in the Moone was published in 1638, the same years as Godwin's Man in the Moone and four years after Kepler's Somnium. Wilkins was instrumental in founding the Royal Society and encouraged the study of astronomy at Oxford and London. ${ }^{38}$ Unlike Godwin, Wilkins includes a full-blown assault on Aristotelianism. The Discovery clearly shows in what direction the genre of the celestial journey has travelled since the writing of Christine's Chemin de Long Estude. Wilkins altogether dispenses with the fictional narrative and presents a series of propositions about lunar and cosmic science. From the literary narrative revelatory of scientia, of which Christine de Pizan's work is a prime example, we have moved to the precursor of the scientific paper. As Marjorie Hope Nicolson points out: '[Wilkins's] Discovery is one of the first important books of modern "popular science", a work written by a man who knew the technicalities of science. ${ }^{39}$ Wilkins clearly sees himself working within the literary tradition of Lucian, Plutarch, Kepler, and Godwin and draws on these works, as well as 
Galileo's Siderius Nuncius, for his lunar science. Yet Wilkins also concludes that a list of numbered propositions supported by evidence, in contrast to literary narrative, can best convey scientific knowledge to a literate audience.

Wilkins fully accepts the Copernican hypothesis (heliocentrism and terrestrial rotation) and also refutes some fundamental tenets of Aristotelian physics. First, Wilkins entertains the possibility of the plurality of worlds rejected by Aristotle, an idea according to Wilkins, that 'doth not contradict any principle of reason'. ${ }^{40}$ Along with Godwin, he rejects the orb of elemental fire. ${ }^{41}$ Proposition number three, which clearly demonstrates his break with Aristotelianism, boldly states: 'that the heavens doe not consist of any such pure matter which can priveledge them from the like change and corruption, as these inferiour bodies are liable unto' ${ }^{42}$ Wilkins has swept aside the barrier of elemental matter, which Aristotle had located at the sphere of the moon. The heavens for him can no longer consist of incorruptible, immaterial ether, but must be made of something more readily accessible to reason and experimentum.

Not only do we see a shift in specific astronomical doctrines in European cosmology from the time of Christine de Pizan to the work of Godwin and Wilkins, but also a profound difference in how the cosmos was perceived. Many of the technical changes in cosmology can be summed up simply as the growing rejection of Aristotelian physics. The book of Genesis and the Hexameral treatises (works combining theological and physical speculation on the first six days of creation) stood at the heart of early medieval cosmology before the Latin translations of Arabic and Greek astronomical texts entered the West. One book, the Bible, provided a coherent theology, physics, and cosmogony. By Wilkins's day, however, theology and biblical exegesis were becoming increasingly irrelevant to both astronomy and astrology, as practitioners of these sciences, especially in astronomy, were focussing their work more on practical computation, geometry, and mathematics than on origins, causes, and metaphysical powers of the Deity. As Wilkins points out regarding extrapolating the nature of the world from divine writ: 'such...absurdities [about nature] have followed, when men looke for the grounds of Philosophie in the words of Scripture'. ${ }^{43}$

\section{Conclusion}

For Christine de Pizan, astrology and astronomy were merely subsciences of theology - astrology represented that speculative ladder which mounts into the stars and reveals the high majesty. Theology in Christine's Livre 
de la Mutacion de Fortune is 'that supercelestial science which comprises all other knowledge'. ${ }^{44}$ The study of Aristotelian metaphysics is likewise only a stepping stone - or ladder - to divine knowledge. We see similar statements regarding the proper place of astronomical and astrological learning within French culture in the work of Christine's contemporary Nicole Oresme. Oresme writes:

...astrology has three very noble ends. The first is to have knowledge of such great matters, for to this, according to the philosophers, is human nature naturally inclined....The second end, and the chief, is that it gives great aid in the knowledge of God the Creator....The third end of astrology and the least important is to ascertain certain dispositions of this lower and corruptible nature, whether present or to come, and nothing beyond that.... [Coopland's translation]. ${ }^{45}$

Oresme, like Christine, defines knowledge of God as the summum bonum of the natural philosopher. Both Wilkins and Godwin have made a complete separation of themselves from nature. Flying to the moon, an imaginative or ecstatic act in the world of Lucian, Macrobius, Dante and Christine de Pizan, in seventeenth-century writers becomes a possible material reality, the possibility of transporting physical bodies from point to point. In Godwin's day, schemes for flying to the moon were being seriously advanced by scientific thinkers. The 1640 edition of Wilkins's The Discovery of a World in the Moone, for example, contained an additional chapter outlining a device for such a lunar voyage. ${ }^{46}$ Wilkins's 1648 work Mathematical Magick: or, the Wonders that may be performed by Mechanical Geometry also contains a description of a flying chariot.

Christine's journey, on the other hand, does not simply involve a movement from one physical locus to another. Christine's flight of speculation culminates in the knowledge of virtue: she undertakes an inward theological and spiritual journey. Stéphane Gompertz alerts us to the integrating and unifying function of Christine's epistemological journey in Le Chemin de Long Estude: 'the voyage [through the spheres] not only links the different regions of the universe, but also differing realms of knowledge; in this resides the journey's totalizing power'. Elevated by her knowledge of the proper ethics of the prince, which she has heard debated in the Court of Reason, Christine undergoes both an inner and outer spiritualization in her travels to the heavenly spheres. Christine writes in the Chemin de Long Estude: 'through knowledge, the 
great treasure of the Understanding, better than gold, is engendered in our breasts; the fruit of such knowledge heals all wounds. Knowledge is the sun whose light illuminates the shadows of our thoughts with its fullness ${ }^{48}$ The growth of inward knowledge involves building the bright, ethereal ladder of speculation in the mind's eye. Sebille suggests that Christine serve as a messenger to earth to report the debates in the court of Reason: Christine therefore truly becomes an 'influence', a spiritualized daemon or angel, transformed into the intermediate aetherial or pneumatic substance possessing the moral understanding that she will breathe into ('influer') the ears of earthly princes. Illuminated by ethical knowledge, she may also be likened to astrological rays transporting the heavenly influences to the terrestrial realm.

In Christine's conception of heaven, a strong link exists between divine knower and the known world; both are described as light and clear in her frequently employed Platonic light-as-knowledge metaphor. In the case of spiritual knowledge, the knower and the known are not distinct epistemological positions. Astronomy or astrology would not have to be studied in the heavens, since study implies a knowledge outside the individual; this separation could not occur in union with God. In heaven, the shining glorified bodies united to their souls in Christine's poem $\mathrm{La}$ Prison de la Vie Humaine, 'will find that they have all forms of knowledge, know all things perfectly, feel the infinite goodness of God'. ${ }^{49}$

In Christine's theory of knowledge, the long road of study requires moral and abstract thought, which then bridges the spatial and epistemological distance between the soul and heaven, the soul's final destination. As the two realms interrelate spiritually, there is no real concept of space or locus in Christine: distance between objects may be physical, but not spiritual, or vice versa. For Godwin and Wilkins, representing the triumph of the new physical, materialist astronomy in their celestial voyage narratives, the material universe is now distinct from the human soul. 
48 Changes in Celestial Journey Literature 1400-1650

\section{References}

1. Gaston de Paris, 'Chronique', Romania 10 (1881) 318: 'un ouvrage dont la valeur poétique est médiocre et qui n'a d'intérêt que pour l'histoire des idées et de l'instruction au XVe siècle'. Unless noted, all translations are my own.

2. Christine de Pizan, Le Livre du Chemin de Long Estude, ed. Robert Püschel (Paris 1887) 413-414: 'le feu et l'iave s'entreheent,/ A destruire l'un l'autre beent.'

3. See Edward Grant, Planets, Stars and Orbs: The Medieval Cosmos, 1200-1687 (Cambridge 1994) 59: 'Medieval society's concept of the origin, structure, and operation of the world was drawn almost exclusively from the Aristotelian-Ptolemaic astronomical and cosmological tradition.' Bernardus Silvestris's Cosmographia has been translated by Winthrop Wetherbee, The Cosmographia of Bernardus Silvestris: A Translation With Introduction and Notes (New York 1973).

4. Richard Lemay, 'The True Place of Astrology in Medieval Science and Philosophy: Towards a Definition', Astrology, Science and Society: Historical Essays, ed. Patrick Curry (Woodbridge, Suffolk 1987) 57-78.

5. Both of these questions are intimately related to Aristotelianism. Aristotle had clearly stated the world was eternal and non-created, while the book of Genesis forced Christian theologians to argue for creation ex nihilo. Aristotle also denied the possibility of other worlds, arguing from his theory of the natural place of the elements. The heaviest element, earth, naturally falls towards the centre of the universe, i.e. the sphere of the earth, while light elements such as fire escape towards the heavens. Multiple worlds entailed multiple centers of attraction, in which case elements would be flying around the cosmos helter skelter. But denying the possibility of multiple created worlds placed a fundamental restriction on an omnipotent being. See Stephen J. Dick, The Plurality of Worlds (Cambridge 1982) and Pierre Duhem, Medieval Cosmology: Theories of Infinity, Place, Time, Void, and the Plurality of Worlds, ed. and trans. Roger Ariew (Chicago 1985) 431-510.

6. Marie-Josèphe Pinet, Christine de Pizan 1364-1430: Étude Biographique et Littéraire (Paris 1927) 423: 'Christine ne cesse de considérer Aristote comme le prince des philosophes.'

7. Christine de Pizan, Christine's Vision, trans. Glenda K. Mcleod, Garland Library of Medieval Literature, vol. 68, series B (New York 1993) 93 n.24.

8. Chemin 636-37. Jane Chance explores the question of female knowledge and its metaphors in 'Christine de Pizan as Literary Mother. Women's Authority and Subjectivity in "The Floure and the Leafe" and "The Assembly of Ladies", The City of Scholars: New Approaches to Christine de Pizan, ed. Margarete Zimmermann and Dina De Rentiis (Berlin 1994) 245-259.

9. Chemin 1602-1610: 'Legiere estoit et portative/ Si qu'on la peust ertortillier/ Et porter sanz soy travaillier/ Par tout le monde, qui voulsist,/ Que ja n'empeschast ne nuisist,/ Non mie que de corde fust/ $\mathrm{Ne}$ d'autre file ne de fust;/ Ne je n'en congnois la matiere,/ Mais longue estoit, fort et legiere.'

10. Christine, following the practice of many medieval and Renaissance writers uses the terms 'astronomie' and 'astrologie' interchangeably. More precise writers followed Ptolemy's division in the Tetrabiblos, which circulated in the west in a widely read Latin translation entitled the Quadripartitum. Ptolemy clearly distinguished two cosmological sciences: the first part of the science of the stars consisted of the study of the appearance and movements of the celestial bodies with respect to the earth (what today we would call

Culture and Cosmos 
astronomy); the second part considered the effects of the heavenly bodies on terrestrial events and human actions (what we would call astrology).

11. Chemin 1824-32: '[Sebille] tout me monstroit, et devisoit/ Des planetes les noms, la force,/ Et de moy enseignier s'efforce/ Les cours des estoilles mouvables/ Et des estans et des errables./ Si m'en dist les proprietez,/ L'effect, les contrarietez,/ Leurs forces et leurs influences/ Et leurs diverses ordenances.'

12. Chemin 1848-9: 'Car sience d'astrologie/ N'ay je pas a l'escole aprise.'

13. Charity Cannon Willard, 'Christine de Pizan: The Astrologer's Daughter' in Mélanges à la Mémoire de Franco Simone, vol. 1 (Genève 1980) 95-111; Charity Cannon Willard, Christine de Pizan: Her Life and Works (New York 1984) 17, 19-22, 97, 104; Edgar Laird, 'Astrology in the Court of Charles V of France, As Reflected in Oxford, St. John's College, MS 164' Manuscripta 34 (1990) 167-176.

14. Lynn Thorndike, A History of Magic and Experimental Science, 8 vols. (New York 1923 - 58) 3.585 .

15. I am working from G.W. Coopland's paraphrase of Oresme's De l'Espere in Nicole Oresme and the Astrologers: A Study of His Livre de Divinacions (Liverpool 1952) 1720.

16. Chemin 1934, 1943.

17. Chemin 1994. For an introduction to the history of this idea, along with excerpts from original texts, see Joscelyn Godwin's Harmony of the Spheres: A Sourcebook of the Pythagorean Tradition in Music (Rochester 1993).

18. Chemin 2010-11.

19. Chemin 2030-34.

20. Chemin 2095.

21. Chemin 2109-2118: '....aussi tost que l'omme naist/ Ou la femme, ja si grant n'est,/ Ceulx [les destinees] yci de sa vie ordenent/ Et sa droite fin lui assenent,/ Bonne ou male, selon les cours/ Ou les planetes ont leurs cours/A l'eure que l'enfant est né./ Mais toutefois Dieux, qui donne/ Leur a ce povoir, dessus est,/ Qui bien garde ce qui lui plaist.'

22. Chemin 2175-84.

23. For example, Le Jugement du Roy de Behaigne and Le Jugement du Roy de Navarre.

24. Barbara K. Altmann, 'Reopening the Case: Machaut's Jugement Poems as a Source in Christine de Pizan', Reinterpreting Christine de Pizan, ed. Earl Jeffrey Richards, Joan Williamson, Nadia Margolis, and Christine Reno (Athens 1992) p 137.

25. The Man in the Moone: or a discourse of a Voyage thither by Domingo Gonsales The Speedy Messenger (London 1638). All references to The Man in the Moone will be from the 2 nd edition of 1657.

26. Lucian, The True History; Plutarch, De Facie in Orbe Lunae; Macrobius, Somnium Scipionis; Dante, Divina Commedia. Marjorie Hope Nicolson surveys some of this literature in A World in the Moon: A Study of the Changing Attitude Toward the Moon in the Seventeenth and Eighteenth Centuries, Smith College Studies in Modern Languages, vol. 17, no. 2 (Northampton, MA 1936).

27. Dictionary of National Biography, ed. Sir Leslie Stephen and Sir Sidney Lee, vol. 8 (Oxford 1917) 56 - 58.

28. Planetary Astronomy from the Renaissance to the rise of Astrophysics, The General History of Astronomy, ed. René Taton and Curtis Wilson, vol. 2, Part A: Tycho Brahe to Newton (Cambridge 1989) 5-7. See also J. L. E. Dryer, A History of Astronomy from Thales to Kepler, rev. W. H. Stahl, ed. 2 (New York 1953) 365-71 and Clarisse Doris Hellman, The Comet of 1577: Its Place in the History of Astronomy (New York 1971).

Culture and Cosmos 
50 Changes in Celestial Journey Literature 1400-1650

29. Godwin 68.

30. Godwin 65.

31. Chemin 1703-22.

32. See Thorndike 6.1-2, 83, 384.

33. H.W. Lawton, 'Bishop Godwin's Man in the Moone', Review of English Studies 7, no. 25 (1931) 41.

34. Chemin 1699-1700: 'comme une petite pelote,/ Aussi ronde q'une balote.'

35. Godwin 58-59.

36. Godwin 60.

37. Kepler's Somnium: The Dream, or Posthumous Work on Lunar Astronomy, trans. Edward Rosen (Madison 1967) 82 n.96.

38. Dictionary of National Biography, 21.264 -7.

39. Marjorie Hope Nicolson, Voyages to the Moon (New York 1948) 93.

40. John Wilkins, The Discovery of a World in the Moone (1638), A Facsimile Reproduction with an Introduction by Barbara Shapiro (Delmar 1973) 25.

41. Wilkins 54.

42. Wilkins 44.

43. Wilkins 40.

44. Christine de Pizan, Le Livre de la Mutacion de Fortune, ed. Suzanne Solente, t. 2 (Paris 1957) 7309-14: 'la superceleste/ Science...Ou est compris science entiere.' See also Christine de Pizan, Le Livre des Fais et Bonnes Meurs du Sage Roy Charles V, ed. Suzanne Solente, vol. 2 (Paris 1936) 18, 'comme l'entencion finale de sapience ou de methaphisique soit pervenir à cognoistre le gouvernement de la cause premiere, c'est Dieu le glorieux, la cognoissance de l'ordre des esperes celestes, auxquelles cognoiscences impossible est venir, senon après astrologie; et toutefois à astrologie nul ne puit parvenir s'ançois n'est philosophe, geomettre et arismetien; par quoy, comme il appert qu'en l'ordre des sciences astrologie et methaphisique sont tres haultes'.

45. Nicole Oresme, Livre de Divinacions in Coopland 113: 'la science du ciel a trois tres nobles fins. La premiere est avoir congnoissance de si tres belles choses car a ce est naturellement humain lignage enclin selon les philosophes......La seconde fin et la plus principale d'astrologie est ce que elle donne grant aide a la congnoissance de Dieu le createur....La tierce fin d'astrologie et la moins principal est congnoistre aucunes disposicions de ceste basse nature corruptible presentes ou avenir et tant et nomplus....'.

46. Barbara Shapiro, 'Introduction,' Wilkins vi.

47. Stéphane Gompertz, 'La voyage allégorique chez Christine de Pisan', in Voyage, Quete, Pelerinage Dans la Literature et la Civilization Medievales, Senefiance No. 2, Cahiers du CUER MA (Paris 1976) 200: 'le voyage ne met pas seulement en contact les régions de l'univers mais aussi les domaines de la connaissance: c'est là que réside sa vertu totalisante.'

48. Chemin 5215-21: 'Par la quelle [la science]le grant tresor/ De conscience, meilleur que or,/ Est conceu en nostre courage,/ Dont le fruit tous maux assouage./ C'est le souleil par quel lumiere/ Ajourne o sa lueur pleniere/ Es tenebres de la pensee.'

49. The Epistle of the Prison of Human Life 60-61: 'ilz se trouveront avoir parfaite sapience, sachans toutes sciences, congnoissans toutes choses parfaitement, sentir l'infinie bonté de Dieu.'

Culture and Cosmos 